jobs. Whether coronary bypass surgery should be undertaken in patients with few symptoms has been intensely debated, but the operation is usually reserved for patients with a stenosis of the left main coronary artery or for those with severe disease of three coronary arteries and impairment of left ventricular function. Patients who have limited exercise ability can more easily be given a "prescription" of activities which they can reasonably expect to do. Those who do well are often encouraged by their performance, and their confidence is more easily restored.

Treatment with $\beta$ blocking drugs reduces reinfarction and mortality after myocardial infarction, ${ }^{2021}$ and a sensible policy is to prescribe them to all patients who will tolerate them. The benefit may be greatest in patients who have sustained a large infarction ${ }^{20-22}$ and ideally these drugs should be started in hospital, where side effects such as hypotension and bradycardia are easily detected. They need not be discontinued before exercise testing. Benefit appears to be conferred for at least 18 months after infarction but may extend up to six years. ${ }^{23}$ Trials of aspirin in varying doses with or without dipyridamole have produced less convincing results. The risk of further infarction is reduced, but a statistically significant reduction in mortality has not been shown. ${ }^{324}$ One $300 \mathrm{mg}$ tablet a day is probably as effective as higher doses ${ }^{26}$ and is unlikely to cause harm; I recommend this to patients who can tolerate aspirin.

Trials of calcium antagonists have been disappointing, although a recent study suggests that diltiazem may confer benefit in some patients. ${ }^{27}$ Angina may develop after infarction, and $\beta$ blockers, calcium antagonists, and nitrates should then be prescribed in the usual way. Patients with symptoms resistant to treatment may need to be referred for coronary angiography, but fortunately such patients are few. Most patients can return to their usual way of life-indeed, one possibly healthier than before they had their infarct.

Peter BlOOMFIELD

Senior Registrar in Cardiology,

Western General Hospital,

Edinburgh EH4 2XU

1 Mulcahy R. Influence of cigarette smoking on morbidity and mortality after myocardial infarction. Br Heart $\mathcal{f} 1983 ; 40: 410-5$.

2 Evans AE. Secondary prevention after myocardial infarction. Lancet 1986;ii:150-1.

3 May GS, Kimberley A, Furberg CD, Passamani ER, DeMets DL. Secondary prevention after myocardial infarction: a review of long term trials. Prog Cardiovasc Dis 1982;24:331-52

4 Oliver MF. Why measure cholesterol after myocardial infarction? $\mathrm{Br}$ Med $\mathcal{F}$ 1984;289:1641-2.

5 Oliver MF, Somerville W. Cardiac conditions. In: Medical aspects of finess to drive; a guide for medical practitioners. London: HMSO, 1985.

6 Seldon WA. Simplifying cardiac rehabilitation. Med $\mathcal{F}$ Aust 1986;144:395.

7 Cooper AJ. Myocardial infarction and advice on sexual activity. Practitioner 1985;229:575-9.

8 Multicenter Post Infarction Research Group. Risk and survival after myocardial infarction. N Engl I Med 1983;309:331-6.

9 Murray DP, Salih M, Tan LB, Murray RG, Littler W. Prognostic stratification of patients after myocardial infarction. Br Heart $\mathcal{Y}$ 1987;57:313-8.

10 Cohn PF. The role of non-invasive cardiac testing after uncomplicated myocardial infarction. N Engl F Med 1983;308:90-3.

11 Brush JE, Brand DA, Acampora D, Chalmer B, Wackers FJ. Use of the initial electrocardiogram to predict in-hospital complications of acute myocardial infarction. $N$ Engl $\mathcal{F}$ Med 1985;312: $1137-41$.

12 Heger JJ, Weyman AE, Wann LS, Dillon JC, Feigenbaum H. Cross sectional echocardiography in acute myocardial infarction: detection and localization of regional left ventricular asynergy. Circulation 1979;60:531-8.

13 Force T, Bloomfield P, O'Boyle JE, Khuri S, Josa M, Parisi AF. Quantitative two-dimensional echocardiographic analysis of regional wall motion in patients with peri-operative myocardial infarction. Circulation 1984;70:233-41.

14 Hutter AM, De Sanctis RW, Flynn T, Yeatman LA. Non transmural myocardial infarction: a comparison of hospital and late clinical course of patients with that of matched patients with transmural anterior and transmural inferior myocardial infarction. Am $\mathcal{J}$ Cardiol 1981;48: 595-602.

15 De Wood M, Stifter WF, Simpson CS, et al. Coronary arteriographic findings soon after non-Q-wave myocardial infarction. $N$ Engl F Med 1986;315:417-22.

16 De Busk RF, Dennis CA. "Submaximal" pre discharge exercise testing after acute myocardial infarction: who needs it? Am F Cardiol 1985;55:499-500.

17 Hamm LF, Stull GA, Crow RS. Exercise testing after myocardial infarction: historic perspective and current uses. Prog Cardiovasc Dis 1986;28:463-76.

18 Jennings K, Reid DS, Hawkins T, Julian DG. Role of exercise testing early after myocardial infarction in identifying candidates for coronary surgery. $B r$ Med $\mathcal{J}$ 1984;288: 185-7.
19 Gibson RS, Watson DD, Cradock GB, et al. Prediction of cardiac events after uncomplicated myocardial infarction: a prospective study comparing pre discharge exercise thallium-201 myocardial infarction: a prospective study comparing pre discharge exercise thallium-201 scintigraphy and coronary angiography. Circulation 1983;68:321-36

20 Friskman WH, Furberg CD, Friedwald WT. $\beta$-Adrenergic blockade for survivors of acute myocardial infarction. $N$ Engl f Med 1984;310:830-7.

21 Yusuf S, Peto R, Lewis J, Collins R, Sleight P. Beta-blockade during and after myocardia infarction: an overview of the randomised trials. Prog Cardiovasc Dis 1985;27:335-71.

22 Griggs TR, Wagner GS, Gettes LS. Beta-adrenergic blocking agents after myocardial infarction an undocumented need in patients at lowest risk. $f$ Am Coll Cardiol 1983;1:1530-3.

23 Petersen TR. Six year follow up of the Norwegian multicenter study on timolol after acute myocardial infarction. N Engl F Med 1985;313:1055-8.

24 Anonymous. Aspirin after myocardial infarction [Editorial]. Lancet 1980; $1: 1172-3$.

25 Klimt CR, Knatterud GL, Stamler J, Meier P. Secondary coronary prevention with persantin and aspirin. $\mathcal{F}$ Am Coll Cardiol 1986;7:251-69.

26 Lewis HD, Davis JW, Archibald DG, et al. Protective effects of aspirin against myocardial infarction and death in men with unstable angina. N Engl F Med 1983;309:396-403.

27 Gibson RS, Boden WE, Theroux $P$, et al. Diltiazem and reinfarction in patients with non-Q-wave myocardial infarction: results of a double-blind randomized multicenter trial. $N$ Engl f Med 1986;315:423-9.

\section{Drinking drivers: the needs for research and rehabilitation}

Despite the current publicity on drinking and driving, it is generally accepted that in Britain only a few drunk drivers are actually apprehended. The law is widely flouted. Consequently random breath testing is much discussed, although in truth the existing law does allow the police randomly to stop vehicles and test the breath of anyone who smells of alcohol or otherwise seems under the influence. An additional call to strengthen drink-driver legislation comes in a new report from Alcohol Concern that argues that since the average driver starts to become more accident prone when his blood alcohol concentration reaches $50 \mathrm{mg} / 100 \mathrm{ml}(10.9$ $\mathrm{mmol} / \mathrm{l}$ ) Britain should follow several other countries and adopt this limit. ${ }^{1}$ Dunbar argues the case for such a change at p 1458.

The report published last week by the Home Office emphasised the importance of alcohol in road accidents among the young. ${ }^{\text {1a }}$ Drivers aged 20-24 have the highest rate of failing breath tests; $39 \%$ of drivers aged $20-24$ who are killed in road accidents have blood alcohol concentrations over the legal limit; $32 \%$ of drink-driving convictions are in people under 25; and 21 is the peak age for drink-driving convictions. But research undertaken by the Home Office shows that much of the problem is undetected: the 3.3 million men aged 17-29 with driving licences drink $2 \cdot 7$ times a week on average, and on half of those occasions they drink more than five units of alcohol, which is likely to put their blood alcohol concentration above the legal limit-and yet on $10 \%$ of these occasions the drinking is followed by driving. Their chance of conviction is, the Home Office calculates, about $0.4 \%$ each time. As the report says, "There appears to be a very considerable drinking and driving problem involving beer drinking young men, to which enforcement of the law is unlikely to be an adequate answer." Only if the young — and their elders - can be persuaded to reduce the amount they drink can we hope for an important fall in the number of times that people drink and drive.

Such discussions obscure the fact, however, that little attention is paid to those drivers who are convicted of drinkdriving offences. Too little is known of their drinking histories. How many, for example, are alcohol dependent and how many receive any treatment? How many are drinking enough alcohol to suffer other problems? How many modify their intake after being apprehended and convicted? 
The difficulty that researchers face in answering these questions is gaining access to convicted drinking drivers. Before drink-driving legislation was widespread the central problems were tackled indirectly. Glatt found that most inpatients in an alcohol treatment unit admitted to driving while intoxicated. ${ }^{2}$ Using prevalence figures from Sweden and Canada, he inferred that alcoholics were about $10 \%$ of those arrested for drink-driving offences. Selzer in the United States in 1963 studied referrals from a judge and produced the more alarming figure of $57 \%{ }^{3}$

Two years later the Grand Rapids study established the supreme importance of alcohol as a cause of fatal traffic accidents and led to legislation in many countries whereby a blood alcohol concentration above a certain limit in a driver was an offence in itself. $^{4}$ With a dramatic increase in convictions and the disease model of alcoholism in its heyday there was a demand for rehabilitation of the driver in addition to legal penalties. Rehabilitation programmes are now operating in all the American states and are widespread in New Zealand, Australia, Scandinavia, Holland, West Germany, and Switzerland. ${ }^{5}$ They also exist to a lesser extent in France. These programmes have generated research mainly concerned with their own efficacy but have also provided answers to the questions posed above. Whereas Selzer's original study was of 67 drivers, Fine and Scoles looked 14 years later at 2300 people in rehabilitation programmes and came to similar conclusions on the prevalence of alcohol dependence. ${ }^{6}$

In Britain the 1967 legislation did not produce the same spark. We have no official policy on rehabilitation, although some local projects are promoted by magistrates and the probation service. ${ }^{7}$ There is thus little opportunity for research, and that which is done is due to the efforts of groups such as the Tayside Safe Driving Project. For the most part in Britain the question of prevalence of alcohol related problems in drunk drivers is not only unanswered but unasked. The drink-driving population remains inaccessible.

Even when accessible the subjects are not necessarily scrutable. The mainstays in case finding of those in the community with alcohol problems are questionnaires, but in a population described by Selzer as "not overtly cooperative" their use must be open to doubt. Dunbar in his samples of recently arrested drivers used serum $\gamma$-glutamyltransferase activity as an index of problem drinking. In one such sample he found that almost a third of those arrested for drinkdriving offences had raised serum $\gamma$-glutamyltransferase activity and that most of these had similar rises five to nine months later. ${ }^{8}$ Given the limited sensitivity of the test this is likely to be an underestimate of the prevalence of those who were problem drinkers. A person already convicted and taking part in rehabilitation is more likely to be honest about his drinking, and researchers using the Michigan alcoholism screening test (MAST) in such populations to screen for problem drinkers find that more than four fifths score positively. ${ }^{90}$ Even allowing for false positives when the test is used with drink-driving offenders, ${ }^{11}$ these results provide an ominous rider to Dunbar's figures. There is currently no possibility of trying to replicate them in Britain.

While rehabilitation programmes enable the subject population to be scrutinised, some doubt both the forensic and clinical benefits of the programmes. Most reviewers do, however, think that they have some value. ${ }^{112}$ There would therefore seem to be no excuse for remaining aloof; effective programmes will come only from refining those already operating. In this respect Britain is already behind most other countries. It may be unrealistic to suppose that clinical and forensic aims can always be dovetailed, but ultimately the costs of both services are borne by the same exchequer. Screening and rehabilitation of drink-driving offenders may pay dividends in either sphere. Currently, however, the convicted drink-driving offender has no incentive to face up to his problem drinking, as Dunbar's follow up figures show. The government is otherwise engaged in an education campaign on drinking and driving that is of questionable efficacy without adequate enforcement. The judiciary and police are embroiled in "back extrapolation" of blood alcohol concentrations, an issue which will complicate rather than simplify prosecution. Consequently the issue of what to learn from and what to do with those drivers who are caught and convicted remains neglected. We think that this is precisely the kind of issue that might well be considered by the new interministerial group on alcohol abuse.

ANThony ClaRe

Professor of psychological medicine M BRISTOW Research registrar

Department of Psychological Medicine, St Bartholomew's Hospital Medical College, London EC1A 7BE

1 Alcohol Concern. The Drinking revolution. London: Alcohol Concern, 1987.

la Working Group on Young People and Alcohol. Report. London: Home Office, 1987.

2 Glatt M. Alcoholism in impaired and drunken driving. Lancet 1964;i:162.

3 Selzer W. Alcoholism, mental illness and the drunken driver. Am J Psychiatry 1963;120:326-31. 4 Borkenstein RF, Crowther RP, Shumate WB, Zeil WB, Zylman R. The role of the drinking driver in traffic accidents. Indiana: University of Indiana. 1964.

5 Waller P. Licensing and other controls of the drinking driver. Stud Alcohol 1985;July (suppl 10): $156-60 \mathrm{~S}$.

6 Fine EW, Scoles $P$. Secondary prevention of alcoholism using a population of offenders arrested for driving while intoxicated. Ann NY Acad Sci 1976;273:637-45.

Martin JP. A course for drivers convicted of drink/driving. F ustice of the Peace 1986;March:182-4. 8 Dunbar J, Martin BT, Devgun MS, Hagart J, Ogston SA. Problem drinking among drunk drivers. BrMed F 1983;286:1319-22. (Tayside Safe Driving Project.)

9 Brown RA. Use of the M.A.S.T. with hospitalized alcoholics, psychiatric patients, drinking drivers and social drinkers. Am $\mathcal{f}$ Drug Alcohol Abuse 1979;6:1375-81.

10 Zung B. Correlates of the M.A.S.T. among DWI offenders. F Clin Psychol 1984;40:607-12.

11 Mann R, Leigh G, Vingilis ER, de Genova K. A critical review of the effectiveness of drink driver rehabilitation programmes. Accident analysis and Prevention 1983;15:441-61.

12 Kunkel E. Driver improvement courses for drink drivers reconsidered. Accident Analysis and Prevention 1983;15:429-39.

\section{Preventing lung cancer}

Treatment of lung cancer is essentially palliative- $90 \%$ of patients die. Prevention is thus vitally important and must mostly be aimed at reducing the numbers who smoke. The signs are not all good: smoking among adults has declined, but more among men than women. ${ }^{1}$ Thus, although the death rate from lung cancer among men has declined by $5 \%$ since a peak in 1980, among women it has increased by $21 \%$. Now women aged 16-19 smoke more than men of the same age, and between 1982 and 1984 the prevalence of smoking rose in this group. ${ }^{12}$ Against this background the Marie Curie Memorial Foundation has just held a meeting on preventing lung cancer that concentrated on health education about smoking in schools and passive smoking. The timing was fortuitous because government legislation may well follow the forthcoming report by Sir Peter Froggett's committee on tobacco and health. 